\title{
DEVELOPMENT OF UNIVERSITY STUDENTS' LINGUOCULTURAL COMPETENCE UNDER CONDITIONS OF CORONAVIRUS PANDEMIC: UKRAINIAN DIMENSION
}

\author{
Alla Bogush, Tetiana Korolova, Oleksandra Popova \\ State institution "South Ukrainian National Pedagogical University \\ named after K. D. Ushynsky”, Odesa, Ukraine
}

Alex-Popova@ukr.net

\begin{abstract}
The aim of the study is to analyse the educational means facilitating the development of the linguocultural competence within the academic environment in Ukraine under conditions of the coronavirus pandemic. About 60 senior students and 15 university instructors giving classes in English and Chinese participated in the research. The research methodology is based on analytical and practical analyses of the normative documents facilitating the correlation of foreign language education standards in Ukraine, Europe and China; interviewing; observation (within the experimental study/training). The results show that all students and instructors admitted the importance of culture-related issues in the process of teaching and learning languages; $99 \%$ of the teaching staff and $75 \%$ of the students chose a more detailed content of culture-related issues to be taught/learnt; $80 \%$ of instructors and $78 \%$ of the students highlighted the importance of organising culture-related events. The research results show that it is crucial to accomplish a balanced integration of language and culture in the teaching process. Teachers should clearly understand what cultural information is significant and how to make efficient use of it by applying digital resources. The key issues teachers should pay attention to are the evaluation of cultural information, its accessibility and the most efficient ways to present it to students.
\end{abstract}

Keywords: university students; linguocultural competence; culturological approach; coronavirus pandemic.

\section{Introduction}

The issue regarding the development of university students' linguocultural competence is always topical and determined by the international liaisons between Ukraine and other countries of the world. This raises the need in the training of highly qualified specialists who can use expertly their foreign language skills in particular profession-related spheres and demonstrate their cultural proficiency in order to maintain constructive relationships with partner states.

Concurrently, the Ukrainian normative documents such as the Laws of Ukraine "On Education", "On Higher Education", the National Strategy for the Development of Education in Ukraine for the period up to 2021 and educational programmes are to be observed, since they regulate the contents of competences to be mastered in compliance with their key-note directions like culture-centricity, preservation and enhancement of national educational traditions, humanisation of education and its integration into the world educational space. In the education standards of Ukraine (Bachelor of Arts and Master degrees) for students majoring in Philology, intercultural and mass communication in its oral and written forms is one of the objectives of education. However, the realisation of the education standards has been hampered by the COVID-19 pandemic nowadays. The developing multipolar cross-cultural relations between Ukraine and both European and oriental countries substantiate the necessity to fit methodological support and the concurrent coronavirus pandemic conditions for effective university training aimed at the students majoring in foreign languages (English, Chinese, in particular) in the framework of the education standards as well as modern inter-governmental cooperation vectors.

The specified reasons precondition the study of the pedagogical (education-related) technologies which could be provided for effective teaching/learning under the designated focus. Considering the abovementioned, we intend to analyse the following issues: specificities of university students' linguocultural competence both in overseas countries and Ukraine; difficulties encountered while developing the competence under study within the coronavirus pandemic (COVID-19); the structure of the linguocultural competence and assessment criteria for students' academic success in this regard; teaching/learning problems and suggestions (culture-targeted training in a foreign language; keeping to local culture-related specificities, requirements and traditions; the need in teachers' advanced training in

(C) Alla Bogush, Tetiana Korolova, Oleksandra Popova. 2021. Published by Igor Sikorsky Kyiv Polytechnic Institute. This is an Open Access article distributed under the terms of the licence CC BY 4.0 
culture-centred aspects); results and discussions concerning approaches to developing university students' linguocultural competence under the conditions of COVID-19 pandemic.

\section{Linguistic and culture-related studies in teaching and learning foreign languages}

The latest publications are focused on culture-centred approaches in teaching and learning foreign languages (Andayani \& Gilang, 2020; Najar, 2019; God \& Zhang, 2019); culture- and nation-related entities in teaching foreign languages (Popova, 2016; Peeters, 2015); intercultural challenges, intracultural practices (Fernández \& Pérez Cañado, 2012); language and intercultural communication (Shin, Zohreh \& Chen, 2011); multiculturalism in the framework of learning foreign languages (Fox \& Diaz-Greenberg, 2006); language through culture values (Prodromou, 1992; Halili \& Doçe, 2020), etc.

Some scholars associate linguocultural, sociocultural and ethnographic aspects with the pedagogical phenomenon "culturological approach" in teaching and learning foreign languages. Andayani and Gilang (2015) study the language as an absolute supporting element of human knowledge; the scholars prove that with language, a nation's culture can be delivered all over the world, preserved, and passed down from generation to generation. Thus, any language system is interconnected with country studies forming a matrix. Mora, Trejo and Roux (2016) examine Mexican novice language teachers in terms of their identity development. The authors highlight the importance of local education, stability in teachers' family context and cultural specificities in teaching languages. However, nowadays the homestay programmes, which allow international students to live with local hosts/families during their studies, can hardly be implemented under the COVID-19 pandemic conditions.

Peeters (2015) are representatives of the natural semantic metalanguage (NSM) approach that covers cultural values abound while teaching/learning foreign languages. They never separate the concept "language" from the concept "culture". In this regard, we can support Popova's (2016) viewpoint regarding the classification determinants of the culturological approach: a cultural profile of the countries the language(s) of which is (are) studied; nation-related cultural heritage; ethno-mentality; nation-marked socio-communication; linguocultural background.

The Ukrainian educators (Chekal et al., 2010) believe that "a high-grade communication - an adequate understanding of two participators of a communicative act - is impossible without knowing the country realities, without the communicants' awareness of the reality both in their native country and in the country the language of which is being studied" (p. 238). The authors confirm the need for the language-targeted and culture-centred (intercultural, cross-cultural, linguocultural) approaches in teaching foreign languages at secondary school, which requires a culture-oriented model of teaching language(s) as well as training future teachers of foreign languages. Popova (2016) correlates language and country studies with the decoding of the semantics of the culture-oriented language units, which involves solving two problems: "1) "extraction" of the nation- and culture-marked connotation from the linguistic units; 2) training in perceiving the country marked language units based on the native speakers' culture and the image similar to the one existing in his / her (speaker's) consciousness, that is, nationally codified (non-subjective) associations" (p.162). In other words, linguocultural approach to teaching foreign languages presupposes the development of communicative competence through language, namely the ability to adequately perceive the speech of interlocutor and authentic texts written in native languages.

Another issue to be taken into account is global multiculturalism. Fox and Diaz-Greenberg (2006) conducted the research involving teacher education candidates enrolled in the foreign / world language licensure programmes in two different universities located in the United States. Their purpose was to find out how critical pedagogy and multicultural education can help meet the challenges that world language teachers experience in the teaching of culture. The researchers reveal the existing difficulties in the integration of the cultural standard in foreign/second language teacher education programme and some of the challenges faced in its practical implementation. They assume that cultural understanding and communication around the world can promote honest dialogue, collaboration across countries as well as open the values of others, which might transform global thinking.

\section{Distance education: alternative teaching and learning support}

Nowadays, distance learning is associated with computer-assisted training programmes, for example, Language in Use 24/7; QDictionary; FVords; EZ Memo Booster; Exerciser; IELTS 7 Trainer; English Grammar in Use. Some Ukrainian scholars (Trotsko and Korotkova, 2018) practice computer technologies for communicating with students of overseas universities in a foreign language with the help of e-mail, Forum, Skype, Net Meeting, etc.; conduct video conferences, round-table discussions 
alongside joint projects. The authors recommend that educational institutions should facilitate the functioning of the virtual educational environment, gradually create accessible online teaching materials, and provide for the development of teachers' ICT-competence. However, very little attention is paid to national and cultural values under the restricted conditions of the COVID-19 pandemic.

Saienko, Semyda and Akhmad (2020) prove that using social networks in ESP benefits to the creation of interactive teaching and learning positive environment, can motivate students and facilitate teaching, learning and interaction processes. Thus, the scholars use social networks for developing language skills, namely listening skills (Podcast, Online Radios, Vlogs, and VoIP); speaking skills (VoIP and Vlogs); reading skills (Blogs); writing skills (Blogging, Microblogging, and Wikis); vocabulary (Online Dictionaries, Word Clouds, Tags, and Visual Word Maps). Researchers come to the conclusion that social networks facilitate students' autonomous study, participation in special projects based on their interests; social networks increase students' motivation, enhance their cognitive abilities, promote their creative thinking, and develop new digital communicative skills, as well as help them face the professional challenges (p. 44). The scholars also stady the features of Moodle platform in contrast to social networking sites (Ghouname, 2020); Blackboard (Al-Nofaie, 2020); mobile applications in language learning (Ying, \& Khe, 2019)

It is clear from the above that today's conditions of COVID-19 pandemic hinder opportunities for developing students' linguocultural competence within course studies of foreign languages; they are modifying teaching methods, forms, and means; assessment criteria are being reconsidered, in this respect. Thus, the way to develop the formulated tasks within the designated purpose is presented in the research.

\section{Research aims}

This paper aims at analysing educational means facilitating the development of the linguocultural competence in Ukraine. A better understanding of the issue under study involves the following objectives:

1) to specify the structure of the competence in accordance with the foreign language education standards;

2) to describe effective teaching tools facilitating the development of linguocultural competence under the conditions of coronavirus pandemic;

3 ) to outline the criteria for the assessment of linguocultural competence level.

In the view of the stated objectives, we can hypothesise that the factors which can facilitate the development of students' linguocultural competence are as follows: culture-targeted training; teachers' advanced training in culture-centred linguistics aspects; digital technology-enhanced learning.

\section{Methods}

\section{Participants}

It should be noted that the initiated study was performed at the State institution "South Ukrainian National Pedagogical University named after K. D. Ushynsky" and the Culture and Education Centre "Confucius Institute" at Ushynsky University within the period of March-December 2020. Fifteen university instructors giving classes in English and Chinese to the students majoring in Philology (Translation Studies: English and Chinese) and Secondary Education (major - Chinese, minor - English) participated in the experiment. Sixty senior students were involved into the experiment. The purpose of the experiment was to assess the students' academic achievements and the quality of the university instructors' work, correspondingly, in terms of developing students' linguocultural competence. Students' participation was voluntary and they were informed about the purpose and procedure of the study. Students could stop their participation without academic consequences.

\section{Data collection and analysing tools}

The key sources for the data collection were theoretical fundamentals on linguocultural competence, academic documentation, students' academic achievements, interviews and questionnaires. Our experiment was primarily aimed at collecting and analysing qualitative results as the hypothesis of our study could be supported by full respondents' answers showing real attitudes, awareness level and educational behavioural differences in participants. Open-ended questions facilitated further scientific insights and helped us develop better assumptions. The results of interviewing the students and instructors were interpreted due to the quantitative (statistical), qualitative and content analyses (see 
Figure 1). The qualitative analysis of students' learning outcomes demonstrated the efficacy and impact of suggested teaching practices for the development of linguocultural competence. Thus, we elaborated the assessment criteria of the phenomena under study (see Appendix 1), which enabled us to develop corresponding assignments and to conduct culture-related curricular and extracurricular activities.

\section{Procedure}

The pedagogical experiment consisted of four stages: 1) studying the structure of the linguocultural competence, developing the course and elaborating the assessment criteria for indicating the proficiency level of the students' linguocultural competence; 2) providing an academic course (15 classes with follow up projects presentation) accompanied with technically-enhanced extracurricular activities aimed at the developing the students' linguocultural competence; 3 ) creating the questionnaires and interviewing students and instructors on necessity and feasibility of the linguocultural competence development by digital resources under conditions of the COVID-19 pandemic; 4) interpreting and analysing the obtained outcomes. Two questionnaires were used: one was designed for students and another was created for university instructors.

Questionnaire 1 (for university students)

1. Do you think it is important for students to be aware of culture-related issues while learning foreign languages?
A. Yes.
B. No.

2. What should students know about culture-related issues?

A. National traditions and customs of the countries the language of which they study.

B. National traditions, customs, norms, moral and cultural values of the countries the language of which they study.

C. National traditions, customs, norms, moral and cultural values of the countries the language of which they study, including culture-related vocabulary.

3. Is it essential to be aware of social and political situations in the above-mentioned countries?
A. Yes.
B. No.

4. What skills (practical experience) are necessary for participating in the dialogue of cultures?

A. Abilities to perform a correct behaviour model, typical of countries representing the source and target languages.

B. Practical experience in performing a correct flexible behaviour model according to moral and aesthetic norms, typical of countries representing the source and target languages.

C. Abilities to keep to a flexible behaviour model according to aesthetic norms.

5. Is it significant to be able to analyse and decode and linguistic features of interlocutors' culturemarked messages?

A. Yes. B. No.

6. Which skills should a person have if he/she is going to efficiently cooperate with foreign partners / colleagues?

A. Skills to elaborate and implement joint plans, social projects; to set goals, tasks, strategies and tactics of individual and collective actions.

B. Skills to elaborate and implement joint plans and social projects.

C. Skills to implement joint plans; to set goals, tasks, strategies and tactics of collective actions.

7. Under conditions of the COVID-19 pandemic....

A. Students can fulfil culture-related assignments independently offline (reading, writing, listening comprehension).

B. Students can fulfil culture-related assignments online (discussing, sharing their opinion, preparing monologues, etc.).

C. Students cannot participate in culture-related events; they can read about them and fulfil certain assignments.

D. Students can participate in culture-related events and fulfil culture-related assignments online using ICT.

Questionnaire 2 (for university instructors)

1. Do you think it is important for students to be aware of culture-related issues while learning foreign languages?
A. Yes.
B. No. 
2. Which culture-related aspects should be included into the content of the learning material while teaching students foreign languages?

A. National traditions and customs of the countries the language of which they study.

B. National traditions, customs, norms, moral and cultural values of the countries the language of which they study.

C. National traditions, customs, norms, moral and cultural values of the countries the language of which they study, including culture-related vocabulary minimum.

3. Is it essential to acquaint students with social and political situations in the above-mentioned countries?
A. Yes.
B. No.

4. What skills (practical experience) are to be trained so that students could constructively participate in the dialogue of cultures?

A. Abilities to perform a correct behaviour model, typical of countries representing the source and target languages.

B. Practical experience in performing a correct flexible behaviour model according to moral and aesthetic norms, typical of countries representing the source and target languages.

C. Abilities to keep to a flexible behaviour model according to aesthetic norms.

5. Is it significant to train students in identifying and deciphering linguistic features of interlocutors' culture-marked messages?
A. Yes.
B. No.

6. Which activities should students be involved in, so that they could achieve mastery in cooperating with foreign partners / colleagues?

A. Activities aimed at elaborating and implementing joint plans, social projects; setting goals, tasks, strategies and tactics of individual and collective actions.

B. Activities aimed at elaborating and implementing joint plans and social projects.

C. Activities aimed at implementing joint plans; setting goals, tasks, strategies and tactics of collective actions.

7. Under the conditions of the COVID-19 pandemic....

A. Instructors can elaborate culture-related assignments for students' independent work in the offline mode (reading, writing, listening comprehension).

B. Instructors can elaborate culture-related assignments for their students to be checked online (discussing, sharing their opinion, preparing monologues, etc.).

C. Instructors cannot involve students into culture-related events; students can read about them and fulfil certain assignments.

D. Instructors can involve their students into culture-related events, elaborate relevant assignments for students to be fulfilled online using ICT.

\section{Results}

According to the results obtained due to the questionnaire and interviewing the respondents, it was found out that students' and teachers' opinions coincided in keynote issues (Fig. 1). Every question of the questionnaire was focused on providing answers to one linguocultural issue: importance of culture-related issues during the language learning, content of culture-related issues, awareness of socio-political situations, dialogue of cultures, decoding of linguistic features, cooperation with foreign partners, culture-related issues relevance under the pandemic conditions.

\begin{tabular}{|c|c|c|c|c|}
\hline & \multicolumn{2}{|c|}{ Students } & \multicolumn{2}{|l|}{ Instructors } \\
\hline Importance of & A & & & $\begin{array}{l}100 \% \\
100 \%\end{array}$ \\
\hline Issues & B & $\begin{array}{l}0 \% \\
0 \%\end{array}$ & & \\
\hline
\end{tabular}




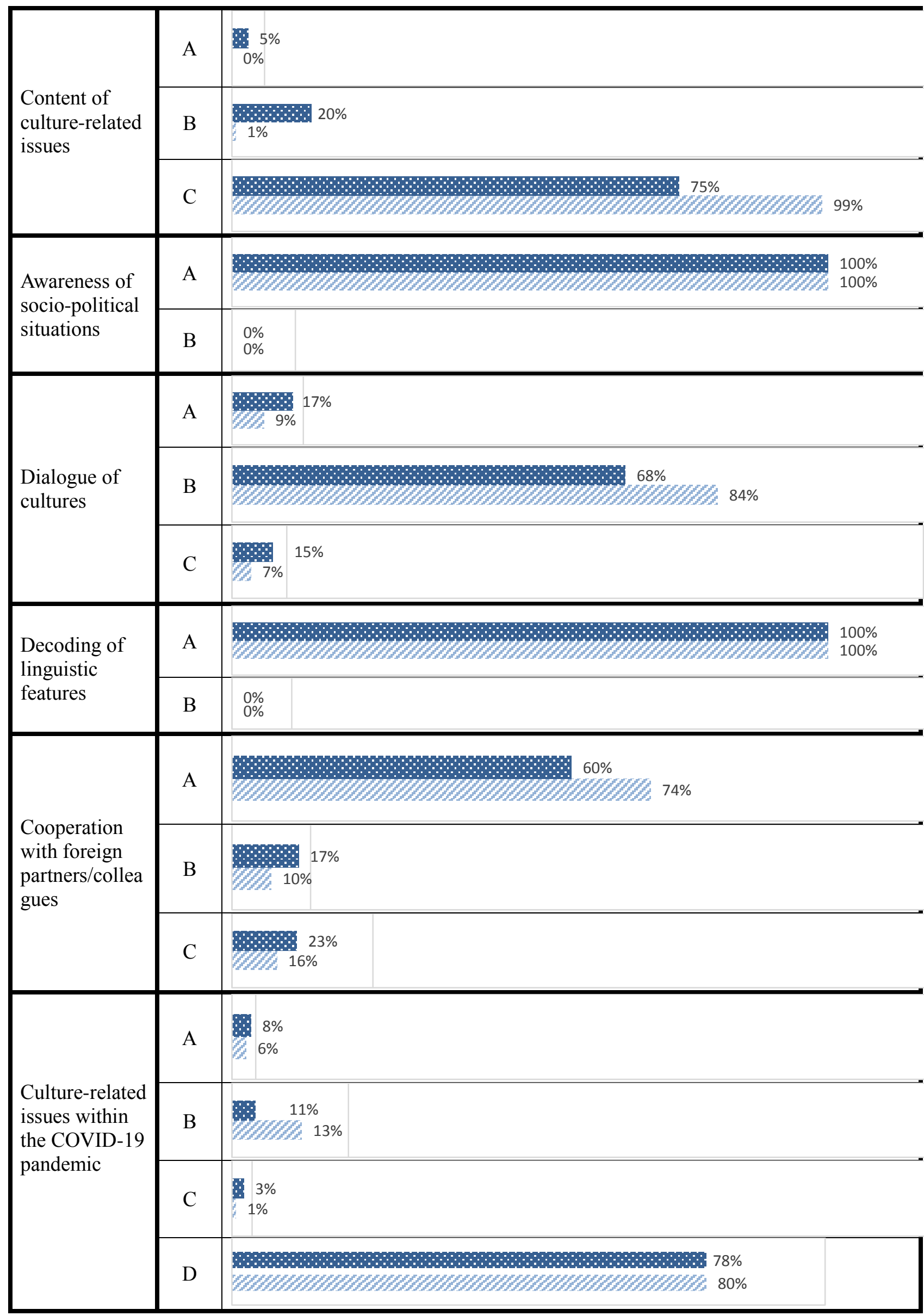

Figure 1. The results of interviewing the university students and instructors 
Presented data confirm that $100 \%$ of the students and instructors admitted the importance of culturerelated issues in the process of teaching and learning languages alongside the abilities to decode linguistic features of interlocutors' culture-marked messages. $100 \%$ of the teaching staff and $98 \%$ of the students agreed that it is essential to be aware of social and political situations in the countries the language of which is learned. The majority of the respondents ( $99 \%$ of the teaching staff and $75 \%$ of the students) chose a more detailed content of culture-related issues to be taught/learnt (awareness of national traditions, customs, norms, moral and cultural values, including culture-related vocabulary minimum). $84 \%$ of the teaching staff and $68 \%$ of the students recognise the necessity of practical experience in performing a correct flexible behaviour model according to moral and aesthetic norms, typical of countries representing the source and target languages, for participating in the dialogue of cultures. Despite the restrictions and inconveniences caused by the COVID-19 pandemic, both the university instructors (80\%) and the students (78\%) highlight the importance of holding culture-related events as well as fulfilling corresponding assignments, in this respect, using alternative teaching / learning platforms (ICT). Cooperation with foreign partners/colleagues, from the perspective of the teaching staff $(74 \%)$ and the students $(60 \%)$, can be efficient if the students are involved in activities aimed at elaborating and implementing joint plans, social projects, setting goals, tasks, strategies and tactics of individual and collective actions.

\section{Discussion}

Since the objectives of our study were to specify the structure of the competence in accordance with the foreign language education standards and to describe effective teaching practices which facilitate the development of the linguocultural competence under conditions of COVID-19 pandemic, it was necessary to identify the most relevant tool to impact the students' achievements in terms of linguocultural competence formation. Having carried out the content analysis of previous studies findings and analysed the results of the questionnaire, we found out that the culturological approach should be considered as a methodological background facilitating the development of the students' linguocultural competence. We define the culturological approach as a set of methods and means of holistic acquisition of culture-related knowledge and skills enabling the development of student's multicultural linguistic identity by studying the Ukrainian (native), English (foreign) and Chinese (foreign) languages. It is interesting to note that cross-cultural language learning provides a balance between national and non-national cultural values, which contributes to a free entry of university students into the modern cultural society.

Our results are in a line with Mora et al. (2016) findings that let us consider the students' linguocultural competence from different perspectives as a unity of theoretical and practical readiness of a student to carry out profession-oriented activities; the students' ability to use integrated in-depth linguistic and sociocultural knowledge combined with profession-relevant skills (and further to improve them) in profession-related activities and intercultural communication; a quality of a bilingual/multilingual person, which ensures his/her physical, mental and spiritual compliance with the requirements of a speciality, qualification standards of his/her profession.

The linguocultural competence is developed through the excellence mastering in three dimensions: linguocultural knowledge, skills and abilities that can be achieved by exploring country studies, observation and training the specificity of the relevant verbal and nonverbal communicative behaviour of a speaker within a particular situation alongside adequate translation tools and techniques for reproducing the original oral or written communication in the target language (Popova, 2015). We outlined the content of each dimension presented in Table 1.

Despite a significant value the linguocultural competence within the competence-based paradigm in teaching foreign languages, today's conditions of the pandemic (COVID-19) make it nearly impossible to develop certain components of the competence: to practice cross-cultural communication offline; to participate in programmes of academic mobility; to hold culture-related events in crowded public areas; to organise non-virtual round-table discussions, conferences, seminars, master classes on education- and culture-related issues involving native speakers, etc. Thus, we can share our experience in using alternative forms, means and methods which could facilitate the development of linguocultural competence under conditions of coronavirus pandemic COVID-19.

The results of the survey illustrate that students recognise the critical role of cultural awareness for efficient communication with representatives of other cultures. During our academic country study course, we highlighted that language performs the cumulative function to store and reflect the extralinguistic experience of the nation. According to teachers' answers, the cultivation of cross-cultural awareness can be performed by familiarizing students with the social and political situation in the country that brings modern 
changes and globalizing cultural trends into the language classroom. It is obvious that today's students are digitally native and their communication horizons are not limited by face-to-face format. Thus, fact explains why students did not accept the lockdown limitations as an obstacle to communicate and study culturerelated issues. This situation caused more challenges to teachers that was the main reason of our study to share the experience of how it is possible to manage with today's limitations. Our questionnaire was as a roadmap for us on our way to solve the problem. It demonstrated students' readiness to cultural studies, teachers' competence in performing the educational practices for linguocultural competence formation and allowed us to elaborate the most relevant formats and methods to achieve our goal.

Table 1. Dimensions of linguocultural competence

\begin{tabular}{|c|c|c|}
\hline Knowledge (awareness) & Practical experience (abilities) & \\
\hline $\begin{array}{l}\text { - background knowledge of } \\
\text { national traditions, customs, } \\
\text { norms, moral and cultural values } \\
\text { of China, Ukraine, Great Britain } \\
\text { (the USA), including culture- } \\
\text { related vocabulary minimum; } \\
\text { - awareness of social and } \\
\text { political situations in the above- } \\
\text { mentioned countries; } \\
\text { - knowledge of these countries' } \\
\text { most significant historical events } \\
\text { and outstanding figures, } \\
\text { interesting geographical places, } \\
\text { sights, cultural monuments, } \\
\text { mythology, literary characters, } \\
\text { philosophical tenets, etc.; } \\
\text { - awareness of aesthetic aspects } \\
\text { regarding verbal and non-verbal } \\
\text { behaviour of native speakers in } \\
\text { accordance with a certain } \\
\text { communicative situation; } \\
\text { - orientation in the specificity of } \\
\text { national humour, irony and other } \\
\text { stylistic peculiarities of mother } \\
\text { tongue and target languages. }\end{array}$ & $\begin{array}{l}\text { - practical experience in the use } \\
\text { of background knowledge in } \\
\text { cross-cultural communication; } \\
\text { - abilities to analyse functioning } \\
\text { mechanisms of social institutions } \\
\text { and constructive cooperation of } \\
\text { partner countries (China, } \\
\text { Ukraine, Great Britain / the USA) } \\
\text { and colleagues within the process } \\
\text { of profession-related activities; } \\
\text { - practical experience in the } \\
\text { identification and adequate } \\
\text { decyphering of hidden } \\
\text { sociocultural aspects of cross- } \\
\text { cultural communication; } \\
\text { - practical experience in } \\
\text { performing a correct flexible } \\
\text { behaviour model in the dialogue } \\
\text { of cultures according to moral } \\
\text { and aesthetic norms, typical of } \\
\text { countries representing the source } \\
\text { and target languages; } \\
\text { - abilities to analyse linguistic } \\
\text { features of interlocutors' culture- } \\
\text { marked messages in order to } \\
\text { select adequate translation and } \\
\text { communication means. }\end{array}$ & $\begin{array}{l}\text { - mastery to use background } \\
\text { knowledge and re-create them } \\
\text { simultaneously into a target text } \\
\text { by adequate means and devices, } \\
\text { preserving national specificity of } \\
\text { a communicative situation; } \\
\text { - skills to act inventively, } \\
\text { deliberatively, ethically } \\
\text { reasonably in relation to } \\
\text { representatives of different } \\
\text { cultures basing on "mentally } \\
\text { processed" information regarding } \\
\text { culture-marked components of } \\
\text { cross-cultural communication; } \\
\text { - skills to cooperate efficiently } \\
\text { (without any conflicts) with } \\
\text { domestic and foreign partners / } \\
\text { colleagues as team (to elaborate } \\
\text { and implement joint plans, social } \\
\text { projects; to set goals, tasks, } \\
\text { strategies and tactics of } \\
\text { individual and collective actions) } \\
\text { being aware of one's own } \\
\text { functions. }\end{array}$ \\
\hline
\end{tabular}

However, it is crucial to define the criteria for the linguocultural competence assessment to ensure that our alternative solutions are as efficient as traditional ones. Through the extensive interpretation of classes observation results and teachers' interview responds, we singled out the following criteria: general cultural, heterosocial intercultural, national-specific, and ethno-traditional (Popova, 2015). The assessment criteria indicators and levels of linguocultural competence are presented in Appendix 1.

With a view of comprehensive understanding of the criteria nature, we referred to previous studies on linguocultural competence development performed by educators worldwide. Thus, Pedrosa (2011) noted that according to the general cultural criterion, students should demonstrate such practical learning outcome as awareness of the concept of a person's "aesthetic culture" in the world format. Our results support his ideas, in fact, we believe that students should demonstrate such practical learning outcomes as skills to act flexibly (according to a flexible model of communicative behaviour), deliberately, aesthetically correct in relation to representatives of different cultures (online, offline, in a mixed-mode). In order to equip students with such kind of knowledge, during our academic course we suggested culture-related literature and assignments dealing with observation and analysing of a person's communicative behaviour (verbal and non-verbal). While preparing online culture-related events, the students had an excellent opportunity to act flexibly and aesthetically correct in relation to their instructors and groupmates. 
Although our results differ slightly from those of Shin et al. (2011), it can nevertheless be considered that the heterosocial intercultural criterion covers such outcomes as:

- awareness of conflict-free cooperation of people within socially heterogeneous groups and interaction of representatives of diverse cultures within a multicultural environment;

- skills to work productively without any conflicts with domestic and foreign partners/colleagues as part of a team (jointly develop and implement plans, social projects, goals, objectives; elaborate strategies and tactics of self-guided and collective actions), being aware of specificities of intercultural communication within distance and eye-to-eye modes.

To achieve the requirements of this criterion, the instructors gave the students the assignments to elaborate presentations aimed at the improvement of socially important issues like "Teaching Chinese and English: a Road to Success", "Secondary and Higher Education in the Framework of the COVID-19 Pandemic", "What Should a Student Majoring in Foreign Languages Know?", "Modern Digital Space: Challenges and Prospects", etc. Students participated in online discussions and had an opportunity to present their ideas using such digital platforms as Padlet or Flipgrid to stimulate further discussions. The students were to present their individual and group presentations on the above-mentioned topics. The collections on Padlet were exchanged with Chinese students who study in Ukrainian universities.

The suggestion of the national-specific criterion is in line with results gained by Ali et al. (2013) and Ahmad et al. (2019), and includes such outcomes as:

- awareness of socio-political situations in the countries the languages of which are studied;

- knowledge of the most important historical events and colourful figures, interesting geographical places, cultural monuments, mythology, literary heroes, etc.;

- knowledge of national specifics of humour and irony of native speakers and target language;

- skills to use background knowledge (of culture-related, socio-political and philosophical issues) and simultaneously decode it when dealing with native speakers online, offline and in a mixed-mode;

- skills to preserve national specificity irrespectively of a communication mode.

Following this criterion, the students studied the material about socio-political, humour- and ironycentred specificities, historical events and colourful figures, interesting geographical places, cultural monuments, mythology, literary heroes within the disciplines "World Literature", "Introduction to Literary Studies", "History of Foreign Literature", "Philosophy". The students listened to authentic podcasts and TED talks on culture-related situations, preserving national specificity irrespectively of a communication mode. They were also given tasks to decode culture-related, socio-political and philosophical issues while listening to authentic sources on these issues as well as to respond in different communication modes.

The use of the ethno-traditional criterion is described by Yagmur and Ehala (2011) who claim that the students should acquire skills and background knowledge of national traditions, customs, norms and values of countries related to the language learning: China, Ukraine, Great Britain (the USA). It will equip students with skills to identify and decode hidden and undisguised ethnocultural aspects in order to select adequate translation and communication means in distance, eye-to-eye, and mixed modes.

Taking into account the above-mentioned criteria, we tried to manage the learning environment to achieve those criteria. Therefore, we offered students a series of online academic courses "Country Studies" suggested by Coursera, Edx, British Council and Education and Culture Centre of China "Confucius Institute" platforms which present information on national traditions, customs, norms and values of national cultures of China, Ukraine, Great Britain (the USA). The assignments were aimed at identifying and decoding the specified issues and translating them adequately in different modes. During the period from March to December (including December) 2020 students took part in the culture-related programmes: the internship distance programmes "Teaching Chinese and English: Current Trends", "Fundamentals of Profession-centred Training in Oriental Studies", etc. in China; the international project "Development of Linguistic and Cultural competence of Employees of Higher Education Institutions" in China;

Also, students were welcomed to join extracurricular activities which facilitated the development of linguocultural competence: online language practise with native speakers at the local, regional and international levels; assistance for instructors in organising online conferences, briefings, presentations, meetings, etc.; translation of culture-related issues and educational documentation.

Intercultural communication, cooperation of Ukrainian teachers and students with teachers from China and the USA, which took place both during the educational process and extracurricular activities, during education- and culture-related events, contributed to the development of the 
students' general competences and social skills, to be more precise: socio-cultural adaptation to a multicultural environment; development of thinking, self-awareness, motivation to educational and professional self-realisation; learning new knowledge and gaining social experience.

Among extra-curricular culture-related events held within March - December (2020) we would like to mention: "Chinese - Ukrainian Spring" (Grand concert, 11th of March), "New Year: Ukraine, the USA, Great Britain" (online cuisine parade), "International Day of Confucius Institutes" (video concert), "Students' Autumn: Festival of Talents" (video-festival), "School leaver's Day" (online presentation), etc. Furthermore, the students organised and participated in online forums, exhibitions, days of culture and history, masterclasses of calligraphy, cooking demonstration, translation workshops and presentations, etc. During the events, students managed to master their linguocultural competence on a transformed platform and demonstrated such skills as:

- to act flexibly, deliberately, aesthetically correct in relation to representatives of different cultures;

- to work productively without any conflicts with their countrymen and foreigners as part of a team (jointly develop and implement plans, projects, goals, objectives; elaborate strategies and tactics of selfguided and collective actions), being aware of specificities of intercultural communication within distance and eye-to-eye modes;

- to use their knowledge of culture-related, socio-political and philosophical issues and simultaneously decode it when dealing with native speakers;

- to preserve national specificity irrespectively of a communication mode;

- to identify and decode hidden and undisguised ethnocultural aspects in order to select adequate translation and communication means.

Thus, the development of the students' linguocultural competence within the COVID-19 pandemic proved to be effective due to the application of a culturological approach and appropriate methodological support of online events and working with digital resources.

\section{Conclusions}

In conclusion, we may assume that the initiated experiment proved to be efficient since it enabled the development of most students' linguocultural competence in the fields of translation (English, Chinese) and teaching foreign languages (Chinese, English) within the conditions of the COVID-19 pandemic. The analysed education standards and scientific literature related to the designated problem (culture-centred approaches in teaching/learning foreign languages; culture- and nation-related entities in teaching foreign languages; intercultural challenges, intracultural practices; language and intercultural communication; multiculturalism in the framework of learning foreign languages; language through cultural values, etc.) have shown that proper methodological support and adequately selected online formats facilitate the development of the students' linguocultural competence.

A particular role is prescribed to the students' self-guided work and extracurricular culture-related activities, involving Ukrainian and foreign university instructors (teachers). Therefore, it is crucial to accomplish a balanced integration of language and culture in the teaching process. It implies that teachers should clearly understand what cultural information is significant and how to make efficient use of it applying digital resources. The key issues teachers should pay attention to are the evaluation of cultural information relevance, assessment of the level of its accessibility and the most efficient ways to present it to students.

Thus, the prospect of further research is seen in elaborating methodological support aimed at accumulating the efforts of Ukrainian and foreign teachers in widening the horizons for teaching foreign languages within a multicultural environment.

\section{References:}

Ahmad, T., Alvi A., \& Ittefaq, M. (2019). The Use of Social Media on Political Participation Among University Students: An Analysis of Survey Results From Rural Pakistan. SAGE Open, 9(3), 215824401986448. https://doi.org/10.1177/2158244019864484

Ali, S., Haider, Z., Munir, F., Khan, H., \& Ahmed, A. (2013). Factors Contributing to the Students Academic Performance: A Case Study of Islamia University Sub-Campus. American Journal of Educational Research, 1(8), 283-289. https://doi.org/10.12691/education-1-8-3

Al-Nofaie, H. (2020). Saudi University Students' Perceptions towards Virtual Education During Covid-19 Pandemic: A Case Study of Language Learning via Blackboard. Arab World English Journal, 11(3) 4-20. https://dx.doi.org/10.24093/awej/vol11no3.1

Andayani, A. \& Gilang, L. (2015). The Effectiveness of Integrative Learning-Based Textbook toward the Local Culture for Foreign Students. International Journal of Humanities and Social Science, 5(10), 197-207. http://www.ijhssnet.com/journal/index/3319 
Andayani, A. \& Gilang, L. (2020). The Understanding of Local Cultural Treasures on Foreign Students in Indonesian Language Learning. Universal Journal of Educational Research, 8(9), 4113-4121. DOI: 10.13189/ujer.2020.080937

Chekal, H. S., Palii, O. A., Potapenko S. I. \& Andriiko, I. F. (2010). Metodyka navchannya inozemnykh mov u zahal'noosvitnikh zakladakh [Methods of Teaching Foreign Languages in Secondary Schools]. Kyiv: Alma-Mater.

Fernández, D. M. \& Pérez Cañado, M. L. (2012). CLIL Teacher Training. In Juan de Dios Martinez Agudo (Ed.), Teaching and Learning English through Bilingual Education (pp.181-212). Cambridge: Cambridge Scholars Publishing,.

Fox, R., \& Diaz-Greenberg, R. (2016). Culture, Multiculturalism, and Foreign Language Standards in U.S. Teacher Preparation Programs: Toward a discourse of dissonance. European Journal of Teacher Education, 29(3), 401-422. https://doi.org/10.1080/02619760600795270

Ghouname, N. (2020). Moodle or Social Networks: What Alternative Refuge is Appropriate to Algerian EFL Students to Learn during Covid-19 Pandemic. Arab World English Journal, 11(3) 21-41. https://dx.doi.org/10.24093/awej/vol11 no3.2

God, Y.T., \& Zhang, H. (2019). Intercultural challenges, intracultural practices: how Chinese and Australian students understand and experience intercultural communication at an Australian university. Higher Education, 78(2), 305-322. https://doi.org/10.1007/s10734-018-0344-0

Halili, E. G., \& Doçe E. (2020). Drama Club: A Creative, Performing, Multidisciplinary and Cultural Laboratory in Tirana University. Universal Journal of Educational Research, 8(10), 4500-4506. https://doi.org/10.13189/ujer.2020.081017

Mora, A. Trejo, P. \& Roux, R. (2019). The complexities of being and becoming language teachers: issues of identity and investment. Language and Intercultural Communication, 16 (2),182-198. https://doi.org/10.1080/14708477.2015.1136318

Najar, U. (2019). The 'intercultural field': interrogating context in intercultural education. Language and Intercultural Communication, 16 (2), 148-163. https://doi.org/10.1080/14708477.2015.1103248

Pedrosa, P. (2011). Cultural significance as a criterion for the conservation of World Heritage.. Masters thesis, Federal University of Pernambuco.

Peeters, B. (2015). Language and culture values: adventures in applied ethnolinguistics. International Journal of Language and Culture, 2 (2), 133-141. https://doi.org/10.1075/ijolc.2.2.001pe

Popova, O. (2015). Criterial approach to professional and speech training targeted for the future translators of the Chinese language. Scientific Bulletin of South Ukrainian National Pedagogical University named after K. D. Ushynsky (Series: Pedagogy), 1(108), 64-68). https://pdpu.edu.ua/vidavnitstvo/145-naukovij-visnik

Popova, O. (2016). Profesiyno-movlennyeva pidhotovka maybutnikh perekladachiv kytays'koyi movy v umovakh universytet $\cdot \mathrm{s}^{\prime} \mathrm{koyi}$ pedahohichnoyi osvity. Monografiya [Professional speech training of future Chinese translators in the conditions of university pedagogical education. Monograph]. Odessa: South Ukrainian National Pedagogical University named after K. D. Ushynsky.

Prodromou, L. (1992). What culture? Which culture? Cross-cultural factors in language learning. English Language Teaching, 46(1), 39-50. https://doi.org/10.1093/elt/46.1.39

Saienko, N., Semyda, O. \& Akhmad I. (2020). Using social networks in teaching ESP to engineering students. Advanced Education, 14,38-45. https://doi.org/10.20535/2410-8286.198083

Shin, J., Eslami, Z., R. \& Chen, W.C. (2011). Presentation of local and international culture in current international English-language teaching textbooks. Language, Culture and Curriculum, 24(3), 253-268. https://doi.org/10.1080/07908318.2011.614694

Trotsko, A. V., \& Korotkova, Y. M. (2018). Using information and communication technologies in the process of teaching foreign languages: the experience of Ukraine and Greece. Information Technologies and Learning Tools, 6(68), 168180. https://journal.iitta.gov.ua/index.php/itlt/article/view/2340

Yagmur, K. \& Ehala, M. (2011). Tradition and innovation in the Ethnolinguistic Vitality theory. Journal of Multilingual and Multicultural Development, 32 (2), 101-110. https://doi.org/10.1080/01434632.2010.541913

Ying, T., \& Khe, F. H. (2019). Examining the utility and usability of mobile instant messaging in a graduate-level course: A usefulness theoretical perspective. Australasian Journal of Educational Technology, 35(4), 128-143. https://doi.org/10.14742/ajet.4571 
Appendix 1. The assessment criteria of linguocultural competence formation

\begin{tabular}{|c|c|c|c|c|}
\hline POINTS & INDICATORS & AWARENESS / SKILLS & GRADES & $\begin{array}{c}\text { ECTS } \\
\text { GRADES }\end{array}$ \\
\hline \multirow{4}{*}{$100-90$} & $\begin{array}{l}\text { general cultural } \\
\text { criterion }\end{array}$ & $\begin{array}{l}\text { Students demonstrate complete awareness of the essence of } \\
\text { the concept of person's "aesthetic culture" in the world } \\
\text { format; they can act flexibly (according to a flexible model } \\
\text { of communicative behaviour), deliberately, aesthetically } \\
\text { correct in relation to representatives of different cultures } \\
\text { (online, offline, in a mixed-mode). }\end{array}$ & \multirow{4}{*}{ VERY GOOD } & \multirow{4}{*}{ A } \\
\hline & $\begin{array}{c}\text { heterosocial } \\
\text { intercultural } \\
\text { criterion }\end{array}$ & $\begin{array}{l}\text { Students are aware of conflict-free cooperation of people } \\
\text { within socially heterogeneous groups and interaction of } \\
\text { representatives of diverse cultures within a multicultural } \\
\text { environment. They can work productively without any } \\
\text { conflicts with Ukrainian and foreign students and teachers as } \\
\text { part of a team (jointly develop and implement plans, social } \\
\text { projects, goals, objectives; elaborate strategies and tactics of } \\
\text { self-guided and collective actions), being aware of } \\
\text { specificities of intercultural communication within distance } \\
\text { and eye-to-eye modes. }\end{array}$ & & \\
\hline & $\begin{array}{l}\text { national- } \\
\text { specific } \\
\text { criterion }\end{array}$ & $\begin{array}{l}\text { Students are aware of socio-political situations in the } \\
\text { countries the languages of which are studied; they } \\
\text { demonstrate excellent knowledge of the most important } \\
\text { historical events and significant figures, interesting } \\
\text { geographical places, cultural monuments, mythology, } \\
\text { literary heroes, etc. They orient in national specifics of } \\
\text { humour and irony of native speakers and target language } \\
\text { representatives. They use background knowledge (of culture- } \\
\text { related, socio-political and philosophical issues) and } \\
\text { simultaneously decode it when dealing with native speakers } \\
\text { online, offline and in a mixed mode. Students render national } \\
\text { specificity in any communication mode. }\end{array}$ & & \\
\hline & $\begin{array}{c}\text { ethno- } \\
\text { traditional } \\
\text { criterion }\end{array}$ & $\begin{array}{l}\text { Students have excellent background knowledge of national } \\
\text { traditions, customs, norms and values of national cultures of } \\
\text { China, Ukraine, Great Britain, the USA, including the } \\
\text { corresponding vocabulary minimum. They can identify and } \\
\text { decode hidden and undisguised ethnocultural aspects in } \\
\text { order to select adequate translation and communication } \\
\text { means in distance, eye-to-eye, and mixed modes. }\end{array}$ & & \\
\hline \multirow{4}{*}{$82-89$} & $\begin{array}{c}\text { general cultural } \\
\text { criterion }\end{array}$ & $\begin{array}{l}\text { Students have good knowledge of the essence of the concept } \\
\text { of a person's "aesthetic culture" in the world format; they } \\
\text { follow flexible models of communicative behaviour, act } \\
\text { deliberately, aesthetically correct in relation to their foreign } \\
\text { language teachers (online, offline, in a mixed-mode). }\end{array}$ & \multirow{4}{*}{ GOOD } & \multirow{4}{*}{$\mathrm{B}$} \\
\hline & $\begin{array}{c}\text { heterosocial } \\
\text { intercultural } \\
\text { criterion }\end{array}$ & $\begin{array}{l}\text { Students are aware of conflict-free cooperation of people } \\
\text { within socially heterogeneous groups and interaction of } \\
\text { representatives of diverse cultures within a multicultural } \\
\text { environment. They can work productively without any } \\
\text { conflicts with Ukrainian and foreign students and teachers as } \\
\text { part of a team (jointly develop and implement plans; } \\
\text { elaborate strategies and tactics of self-guided and collective } \\
\text { actions), being aware of specificities of intercultural } \\
\text { communication within distance and eye-to-eye modes. }\end{array}$ & & \\
\hline & $\begin{array}{l}\text { national- } \\
\text { specific } \\
\text { criterion }\end{array}$ & $\begin{array}{l}\text { Students are aware of socio-political situations in the } \\
\text { countries the languages of which are studied; they } \\
\text { demonstrate good knowledge of the most important } \\
\text { historical events and colourful figures, interesting } \\
\text { geographical places, cultural monuments, mythology, } \\
\text { literary heroes, etc. They are aware of the main national } \\
\text { specifics of humour and irony of native speakers and target } \\
\text { language representatives. They use background knowledge } \\
\text { and decode it when dealing with native speakers online, } \\
\text { offline and in a mixed-mode. Students render national } \\
\text { specificity in major communication modes. }\end{array}$ & & \\
\hline & $\begin{array}{c}\text { ethno- } \\
\text { traditional } \\
\text { criterion }\end{array}$ & $\begin{array}{l}\text { Students have good background knowledge of national } \\
\text { traditions, customs, norms and values of national cultures of } \\
\text { China, Ukraine, Great Britain, the USA, including the } \\
\text { corresponding vocabulary minimum. They can identify and } \\
\text { decode hidden and undisguised ethnocultural aspects and use }\end{array}$ & & \\
\hline
\end{tabular}




\begin{tabular}{|c|c|c|c|c|}
\hline & & $\begin{array}{l}\text { adequate translation and communication means in distance, } \\
\text { eye-to-eye, and mixed modes. }\end{array}$ & & \\
\hline \multirow{4}{*}{$74-81$} & $\begin{array}{l}\text { general cultural } \\
\text { criterion }\end{array}$ & $\begin{array}{l}\text { Students have sufficient knowledge of the essence of the } \\
\text { concept of a person's "aesthetic culture" in the world format; } \\
\text { they follow flexible models of communicative behaviour } \\
\text { suggested by their instructors, behave deliberately, } \\
\text { aesthetically correct in relation to their foreign language } \\
\text { teachers (online, offline, in a mixed-mode). }\end{array}$ & \multirow{4}{*}{ SUFFICIENT } & \multirow{4}{*}{$\mathrm{C}$} \\
\hline & $\begin{array}{c}\text { heterosocial } \\
\text { intercultural } \\
\text { criterion }\end{array}$ & $\begin{array}{l}\text { Students are aware of conflict-free cooperation of people } \\
\text { within socially heterogeneous groups and interaction of } \\
\text { representatives of diverse cultures within a multicultural } \\
\text { environment. They can work productively with Ukrainian } \\
\text { and foreign students and teachers as part of a team (jointly } \\
\text { develop and implement plans; elaborate strategies and tactics } \\
\text { of self-guided and collective actions), but sometimes they } \\
\text { neglect specificities of intercultural communication within } \\
\text { distance and / or eye-to-eye modes. }\end{array}$ & & \\
\hline & $\begin{array}{l}\text { national- } \\
\text { specific } \\
\text { criterion }\end{array}$ & $\begin{array}{l}\text { Students have general ideas regarding socio-political } \\
\text { situations in the countries the languages of which are } \\
\text { studied; they demonstrate sufficient knowledge of the most } \\
\text { important historical events and colourful figures, interesting } \\
\text { geographical places, cultural monuments, mythology, } \\
\text { literary heroes, etc. They are aware of the main national } \\
\text { specifics of humour and irony of native speakers and target } \\
\text { language representatives. They use background knowledge } \\
\text { when dealing with native speakers online, offline and in a } \\
\text { mixed-mode. Students render national specificity in major } \\
\text { communication modes. }\end{array}$ & & \\
\hline & $\begin{array}{l}\text { ethno- } \\
\text { traditional } \\
\text { criterion }\end{array}$ & $\begin{array}{l}\text { Students have sufficient background knowledge of national } \\
\text { traditions, customs, norms and values of national cultures of } \\
\text { China, Ukraine, Great Britain (the USA). They can identify } \\
\text { and decode undisguised ethnocultural aspects and use } \\
\text { adequate translation and communication means in distance, } \\
\text { eye-to-eye, and mixed modes. }\end{array}$ & & \\
\hline \multirow{5}{*}{$64-73$} & $\begin{array}{l}\text { general cultural } \\
\text { criterion }\end{array}$ & $\begin{array}{l}\text { Students have basic knowledge of the essence of the concept } \\
\text { of a person's "aesthetic culture" in the world format; they } \\
\text { consult their instructors regarding a preferable model of } \\
\text { communicative behaviour, behave deliberately, aesthetically } \\
\text { correct in relation to their foreign language teachers (online, } \\
\text { offline, in a mixed-mode). }\end{array}$ & \multirow{4}{*}{ SATISFACTORY } & \multirow{4}{*}{$\mathrm{D}$} \\
\hline & $\begin{array}{c}\text { heterosocial } \\
\text { intercultural } \\
\text { criterion }\end{array}$ & $\begin{array}{l}\text { Students are partially aware of conflict-free cooperation of } \\
\text { people within socially heterogeneous groups and interaction } \\
\text { of representatives of diverse cultures within a multicultural } \\
\text { environment. In general, they can work productively with } \\
\text { Ukrainian and foreign students and teachers as part of a team } \\
\text { (participate in developing and implementing plans under the } \\
\text { guidance of their instructors; partially fulfil self-guided and } \\
\text { collective actions). Still, they sometimes neglect specificities } \\
\text { of intercultural communication within distance and / or eye- } \\
\text { to-eye modes. }\end{array}$ & & \\
\hline & $\begin{array}{l}\text { national- } \\
\text { specific } \\
\text { criterion }\end{array}$ & $\begin{array}{l}\text { Students have basic ideas regarding socio-political situations } \\
\text { in the countries the languages of which are studied; they } \\
\text { demonstrate satisfactory knowledge of the most important } \\
\text { historical events and colourful figures, interesting } \\
\text { geographical places, cultural monuments, mythology, and } \\
\text { literary heroes. They are aware of some national specifics of } \\
\text { humour and irony of native speakers and target language } \\
\text { representatives. They use basic background knowledge when } \\
\text { dealing with native speakers online, offline and in a mixed- } \\
\text { mode. Students feel difficulty in rendering national } \\
\text { specificity in major communication modes. }\end{array}$ & & \\
\hline & $\begin{array}{l}\text { ethno- } \\
\text { traditional } \\
\text { criterion }\end{array}$ & $\begin{array}{l}\text { Students have satisfactory background knowledge of } \\
\text { national traditions, customs, norms and values of national } \\
\text { cultures of China, Ukraine, and Great Britain. They can } \\
\text { identify main undisguised ethnocultural aspects and use } \\
\text { corresponding translation and communication means in } \\
\text { distance, eye-to-eye, and mixed-modes. }\end{array}$ & & \\
\hline & $\begin{array}{l}\text { general cultural } \\
\text { criterion }\end{array}$ & $\begin{array}{l}\text { Students have elementary knowledge of the essence of the } \\
\text { concept of a person's "aesthetic culture" in the world format; }\end{array}$ & & \\
\hline
\end{tabular}




\begin{tabular}{|c|c|c|c|c|}
\hline \multirow{3}{*}{$60-63$} & $\begin{array}{l}\text { heterosocial } \\
\text { intercultural } \\
\text { criterion }\end{array}$ & $\begin{array}{l}\text { they constantly consult their instructors regarding a } \\
\text { preferable model of communicative behaviour. From time to } \\
\text { time, they fail to behave deliberately or aesthetically correct } \\
\text { in relation to their foreign language teachers and groupmates } \\
\text { (online, offline, in a mixed mode). } \\
\text { Students are partially aware of conflict-free cooperation of } \\
\text { people within socially heterogeneous groups and interaction } \\
\text { of representatives of diverse cultures within a multicultural } \\
\text { environment. They experience difficulty in working } \\
\text { productively both with Ukrainian and foreign students and } \\
\text { teachers as part of a team (they sometimes participate in } \\
\text { developing and implementing plans under the guidance of } \\
\text { their instructors; partially fulfil self-guided and collective } \\
\text { actions). They sometimes neglect specificities of } \\
\text { intercultural communication within distance and / or eye-to- } \\
\text { eye modes. }\end{array}$ & \multirow{3}{*}{$\begin{array}{c}\text { LOW } \\
\text { SATISFACTORY }\end{array}$} & \multirow{3}{*}{$\mathrm{E}$} \\
\hline & $\begin{array}{l}\text { national- } \\
\text { specific } \\
\text { criterion }\end{array}$ & $\begin{array}{l}\text { Students have elementary ideas regarding socio-political } \\
\text { situations in the countries the languages of which are } \\
\text { studied; they know some important historical events and } \\
\text { significant figures, have some ideas about interesting } \\
\text { geographical places, cultural monuments, and literary } \\
\text { heroes. They are aware of some national specifics of humour } \\
\text { and irony of native speakers and target language } \\
\text { representatives. They feel difficulty in using their } \\
\text { background knowledge when dealing with native speakers } \\
\text { online, offline and in a mixed-mode or rendering national } \\
\text { specificity in major communication modes. }\end{array}$ & & \\
\hline & $\begin{array}{l}\text { ethno- } \\
\text { traditional } \\
\text { criterion }\end{array}$ & $\begin{array}{l}\text { Students have basic background knowledge of national } \\
\text { traditions, customs, norms and values of national cultures of } \\
\text { China, Ukraine, Great Britain. They can identify the main } \\
\text { undisguised ethnocultural aspects, but they feel difficulty in } \\
\text { selecting corresponding translation and communication } \\
\text { means in distance, eye-to-eye, and mixed modes. }\end{array}$ & & \\
\hline \multirow{6}{*}{$35-59$} & $\begin{array}{c}\text { general cultural } \\
\text { criterion }\end{array}$ & $\begin{array}{l}\text { Students have poor knowledge of the essence of the concept } \\
\text { of a person's "aesthetic culture" in the world format; they } \\
\text { seldom behave deliberately or aesthetically correct in } \\
\text { relation to their foreign language teachers and groupmates } \\
\text { (online, offline, in a mixed-mode). }\end{array}$ & \multirow{4}{*}{ LOW } & \multirow{4}{*}{ FX } \\
\hline & $\begin{array}{c}\text { heterosocial } \\
\text { intercultural } \\
\text { criterion }\end{array}$ & $\begin{array}{l}\text { Students do not demonstrate awareness of conflict-free } \\
\text { cooperation of people within socially heterogeneous groups } \\
\text { and interaction of representatives of diverse cultures within a } \\
\text { multicultural environment. They cannot work productively } \\
\text { both with Ukrainian and foreign students and teachers as part } \\
\text { of a team. They neglect specificities of intercultural } \\
\text { communication within distance and / or eye-to-eye modes. }\end{array}$ & & \\
\hline & $\begin{array}{l}\text { national- } \\
\text { specific } \\
\text { criterion }\end{array}$ & $\begin{array}{l}\text { Students are not aware of socio-political situations in the } \\
\text { countries the languages of which are studied; they have poor } \\
\text { knowledge of important historical events, significant figures, } \\
\text { interesting geographical places, cultural monuments, and } \\
\text { literary heroes. They are aware of some national specifics of } \\
\text { humour and irony of native speakers and target language } \\
\text { representatives. They fail to use their background knowledge } \\
\text { when dealing with native speakers online, offline and in a } \\
\text { mixed-mode or rendering national specificity in major } \\
\text { communication modes. }\end{array}$ & & \\
\hline & $\begin{array}{c}\text { ethno- } \\
\text { traditional } \\
\text { criterion }\end{array}$ & $\begin{array}{l}\text { Students have poor background knowledge of national } \\
\text { traditions, customs, norms and values of national cultures of } \\
\text { China, Ukraine, Great Britain. They can hardly identify the } \\
\text { main undisguised ethnocultural aspects; they feel difficulty } \\
\text { in selecting corresponding translation and communication } \\
\text { means in distance, eye-to-eye, and mixed modes. }\end{array}$ & & \\
\hline & $\begin{array}{c}\text { general cultural } \\
\text { criterion }\end{array}$ & $\begin{array}{l}\text { Students are not aware of the essence of the concept of a } \\
\text { person's "aesthetic culture"; they do not follow adequate } \\
\text { models of communicative behaviour, they do not behave } \\
\text { deliberately or aesthetically correct in relation to their } \\
\text { foreign language teachers and groupmates (online, offline, in } \\
\text { a mixed-mode). }\end{array}$ & & \\
\hline & $\begin{array}{l}\text { heterosocial } \\
\text { intercultural }\end{array}$ & $\begin{array}{l}\text { Students are not aware of the conflict-free cooperation of } \\
\text { people within socially heterogeneous groups and interaction }\end{array}$ & & \\
\hline
\end{tabular}




\begin{tabular}{|c|c|c|c|c|}
\hline \multirow{3}{*}{$0-34$} & criterion & $\begin{array}{l}\text { of representatives of diverse cultures within a multicultural } \\
\text { environment. They do not have any desire to work } \\
\text { productively both with Ukrainian and foreign students and } \\
\text { teachers as part of a team. They neglect specificities of } \\
\text { intercultural communication within distance and / or eye-to- } \\
\text { eye modes. }\end{array}$ & \multirow{3}{*}{ FULL FAILURE } & \multirow{3}{*}{$\mathrm{F}$} \\
\hline & $\begin{array}{l}\text { national- } \\
\text { specific } \\
\text { criterion }\end{array}$ & $\begin{array}{l}\text { Students are not aware of socio-political situations in the } \\
\text { countries the languages of which are studied; they have poor } \\
\text { knowledge of important historical events, colourful figures, } \\
\text { interesting geographical places, cultural monuments, and } \\
\text { literary heroes. They are not aware of the specifics of } \\
\text { humour and irony of native speakers and target language } \\
\text { representatives. They cannot deal with native speakers } \\
\text { online, offline and in a mixed-mode in nationally marked } \\
\text { situations. }\end{array}$ & & \\
\hline & $\begin{array}{c}\text { ethno- } \\
\text { traditional } \\
\text { criterion }\end{array}$ & $\begin{array}{l}\text { Students are not aware of the national traditions, customs, } \\
\text { norms and values of the national cultures of China, Ukraine, } \\
\text { Great Britain. They cannot identify main undisguised } \\
\text { ethnocultural aspects or select corresponding translation and } \\
\text { communication means in any mode. }\end{array}$ & & \\
\hline
\end{tabular}

Received: February 15, 2021

Accepted: April 27, 2021 